
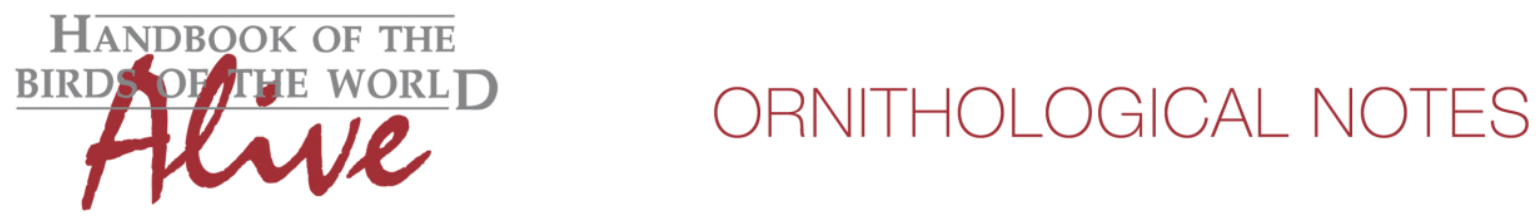

\title{
Notes on the vocalizations of Scaly-breasted Wren-babbler (Pnoepyga albiventer)
}

Peter Boesman

In the following we briefly analyze and compare voice of the different races of Scaly-breasted Wren-babbler (Pnoepyga albiventer). We also try to quantify the extent of any vocal differences using the criteria proposed by Tobias et al. (2010), as a support for taxonomic review. We have made use of sound recordings available on-line from Xeno Canto (XC).

Voice has already been analyzed in Päckert et al. (2013), concluding that there is a significant vocal difference in frequency and time parameters between Nepal and China populations, the latter being longer in duration and having a narrower frequency range. These findings were summarized in the following figure:

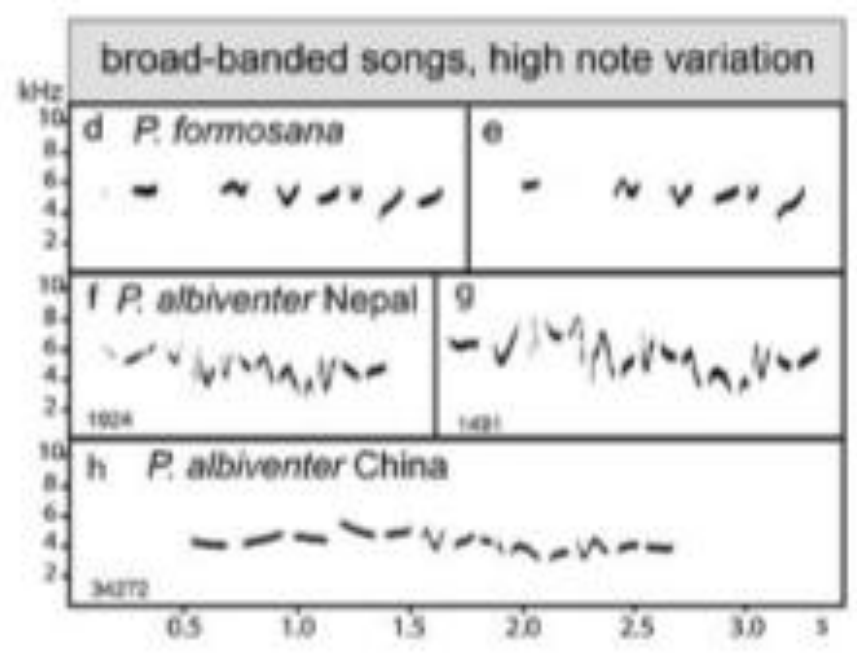

As apparently no recordings were analyzed from intermediate regions (Bhutan and NE India), and quite a few recordings are available, we will reassess vocal differences here, which will also allow quantification according to Tobias criteria.

A few examples:

palidior

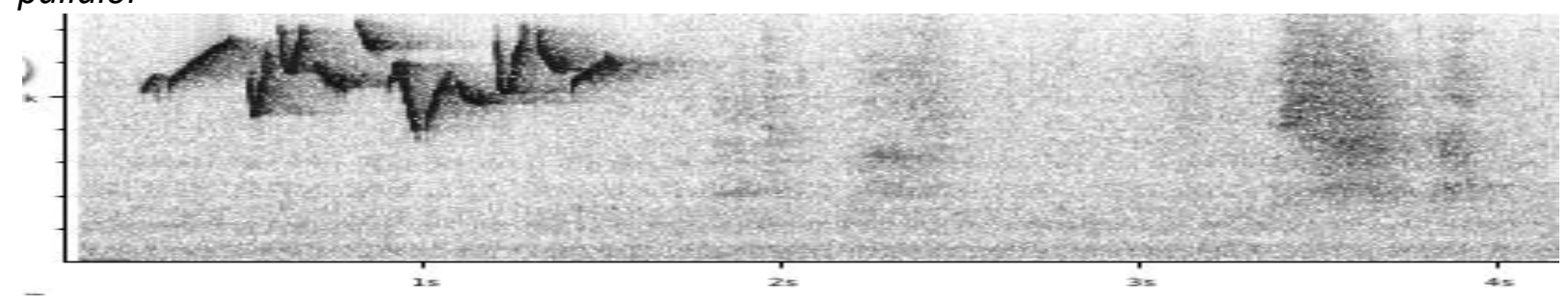


HANDBOOK OF THE

BIRDPPIJE WORLD ORNITHOLOGICAL NOTES

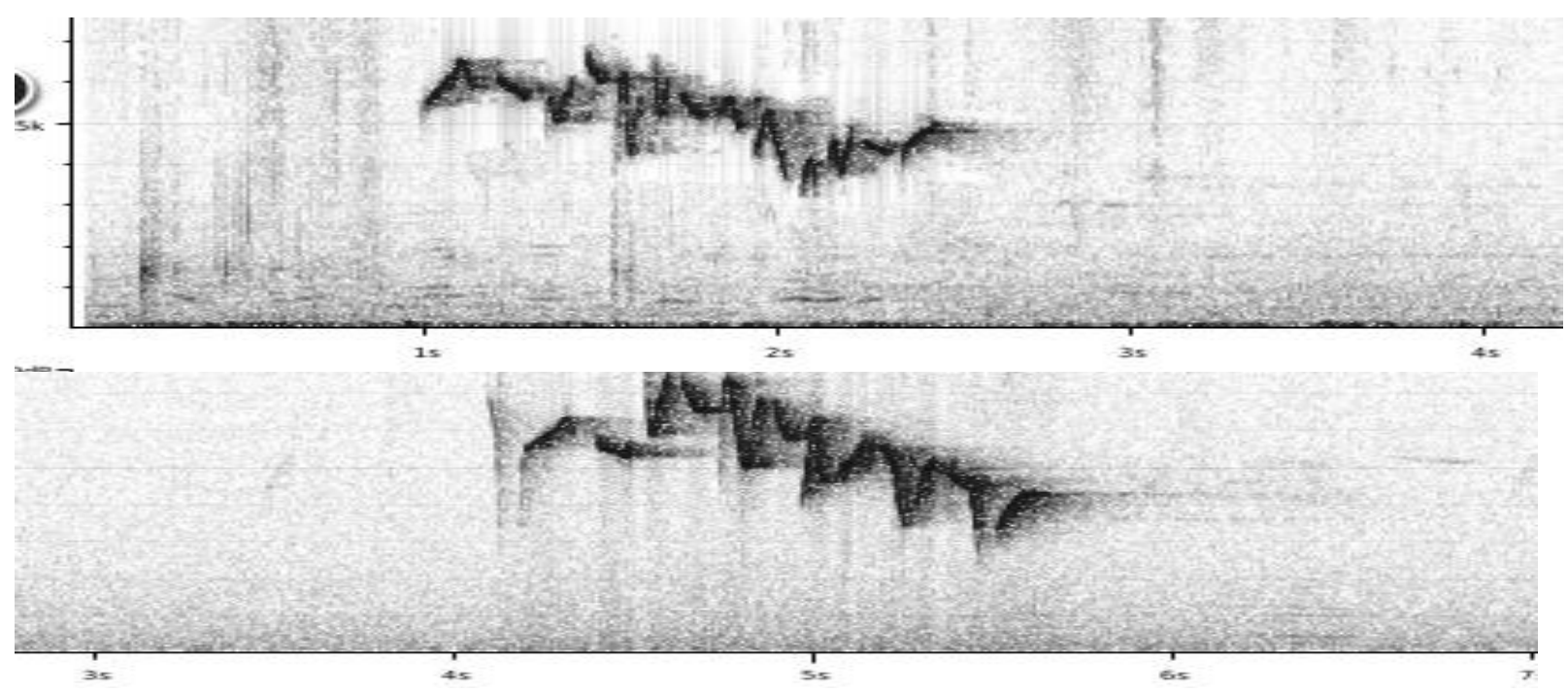

albiventer
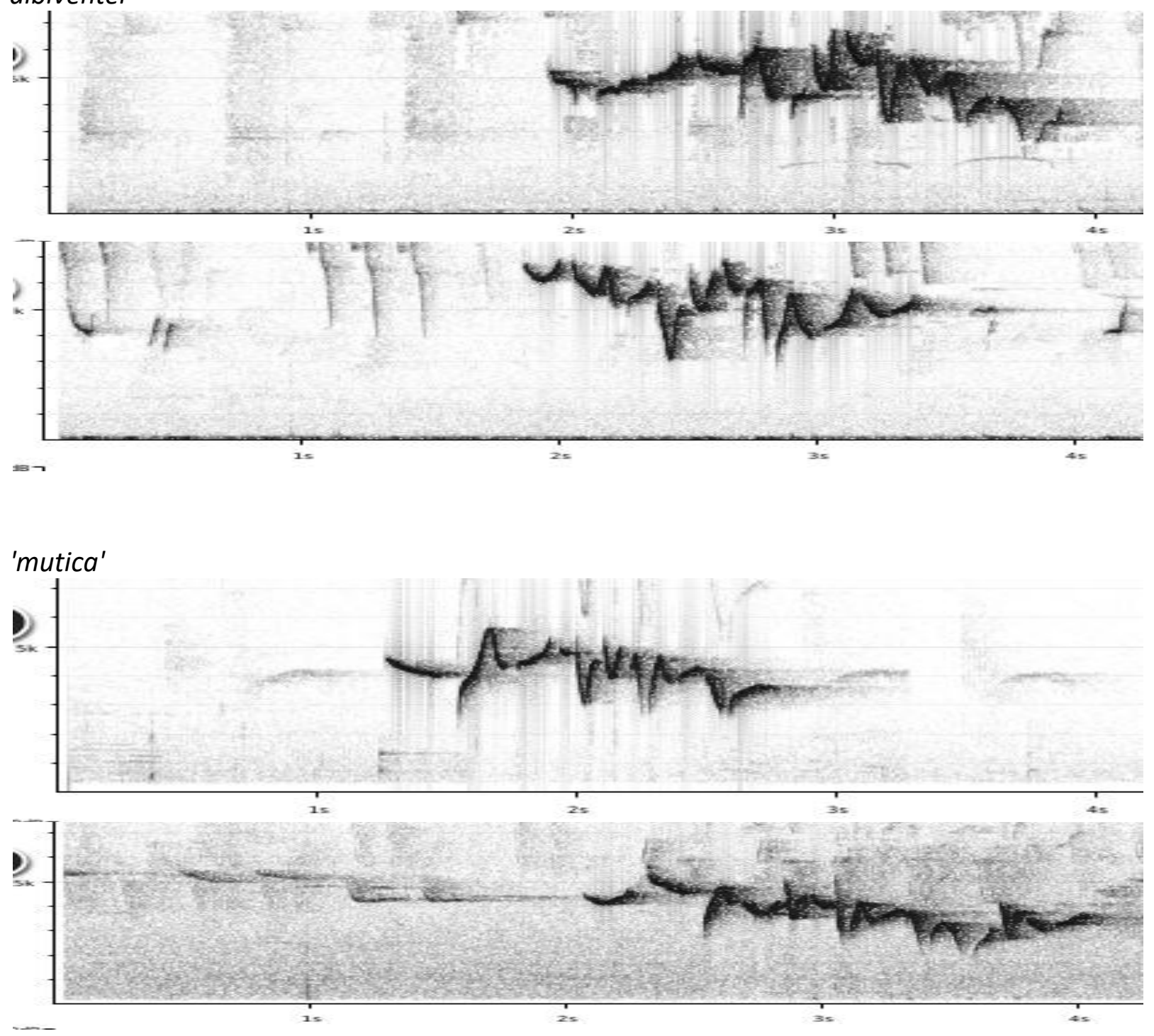

2 

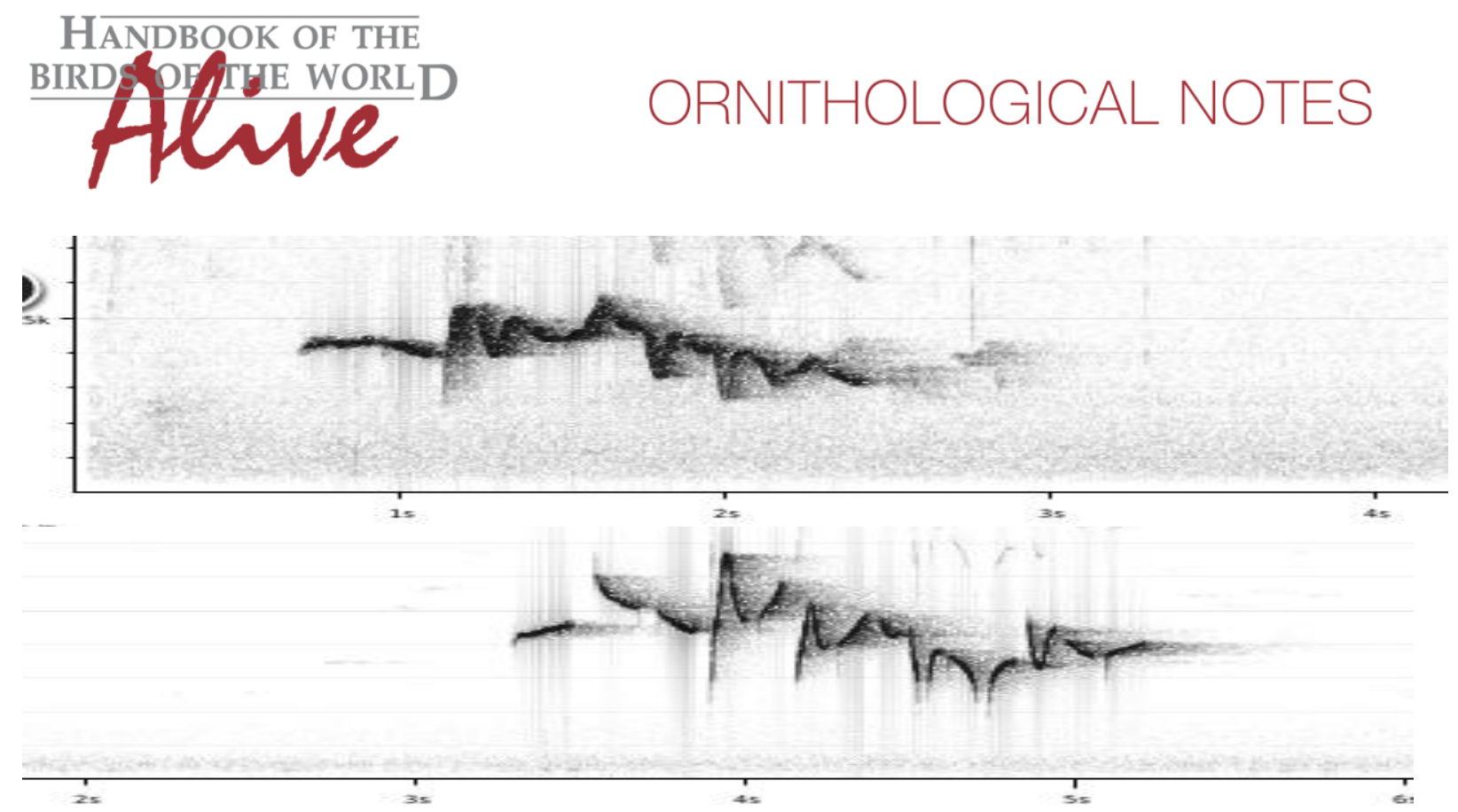

From the above, we can deduct that sonograms for Chinese mutica don't show such a striking difference as depicted in Päckert et al. (2013). We can nevertheless deduct that e.g. 3 of the 4 examples from China stay below $6 \mathrm{kHz}$, while all others go above $6 \mathrm{kHz}$. This may be somewhat clinal however: palidior reaches highest frequencies, then albiventer, then 'mutica'. Given that vocal differences are clearly not that straightforward I have made measurements of the basic sound parameters:

palidior $(n=3)$

max. freq.

$6670-7400 \mathrm{~Hz}$

min. freq.

$2370-3700 \mathrm{~Hz}$

freq. range

$3300-5000 \mathrm{~Hz}$

\# elements

12 - 15

total length

$1.33-1.54 \mathrm{~s}$

av. pace (s/element)

$0.10-0.11$

albiventer $(n=7)$

max. freq.

$6400-7500 \mathrm{~Hz}$

min. freq.

$2100-2900 \mathrm{~Hz}$

freq. range

$3700-4800 \mathrm{~Hz}$

\# elements

$11-16$

total length

$1.53-2.07 \mathrm{~s}$

av. pace (s/element)

$0.11-0.14$

'mutica' ( $\mathrm{n}=4)$

max. freq.

$5450-6500 \mathrm{~Hz}$

min. freq.

freq. range

$1611-2400 \mathrm{~Hz}$

\# elements

$3100-4700 \mathrm{~Hz}$

total length

$11-16$

av. pace (s/element)

$1.48-1.96 \mathrm{~s}$

$0.12-0.135$

It is clear that maximum frequency is the most distinctive parameter for 'mutica'. Minimum frequency is rather clinal between races. All other parameters show less pronounced differences (including frequency range and phrase duration, for which we can't confirm the findings of Päckert et al. (2013)). 

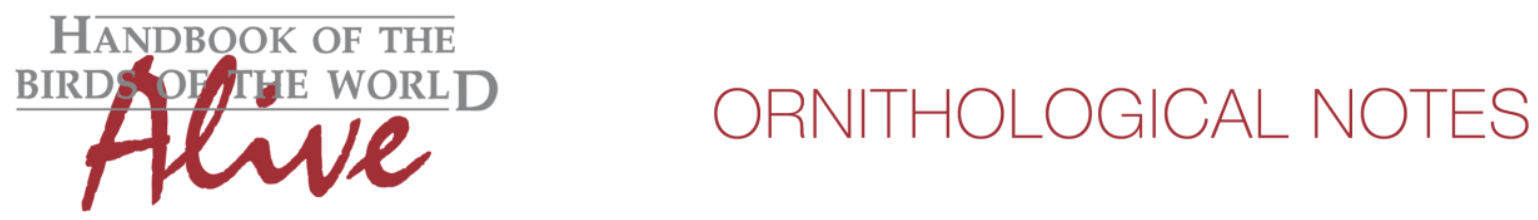

We therefore finalize with an effect size calculation of combined palidior/albiventer vs. 'mutica' for maximum frequency:

palidior/albiventer $(\mathrm{n}=10) \quad$ av. $6968 \mathrm{~Hz} \quad$ SD $334 \mathrm{~Hz}$

'mutica' $(\mathrm{n}=4)$

av. $5762 \mathrm{~Hz} \quad$ SD $429 \mathrm{~Hz}$

-> Effect size 3.13

$\rightarrow$ score 2

We can thus conclude that 'mutica' indeed shows some vocal difference compared to palidior/albiventer, but this difference seems to be rather minor and may well be the result of a clinal change from west to east.

This note was finalized on 12th February 2016, using sound recordings available on-line at that moment. We would like to thank in particular the sound recordists who placed their recordings for this species on XC: Nick Athanas, Mike Catsis, Subhajit Chaudhuri, Brian Cox, Niels Poul Dreyer, Peter Ericsson, Frank Lambert, Antero Lindholm, Mike Nelson, Mathias Ritschard, Sudipto Roy, Ante Strand, Joshi Viral and George Wagner.

\section{References}

Päckert, M., Martens, J., Liang, W., Hsu, W.-C. \& Sun, Y.-H. (2013). Molecular genetic and bioacoustic differentiation of Pnoepyga wren-babblers. J. Orn.154(2): 329-337.

Tobias, J.A., Seddon, N., Spottiswoode, C.N., Pilgrim, J.D., Fishpool, L.D.C. \& Collar, N.J. (2010). Quantitative criteria for species delimitation. Ibis 152(4): 724-746.

\section{Recommended citation}

Boesman, P. (2016). Notes on the vocalizations of Scaly-breasted Wren-babbler (Pnoepyga albiventer). HBW Alive Ornithological Note 233. In: Handbook of the Birds of the World Alive. Lynx Edicions, Barcelona. (retrieved from http://www.hbw.com/node/932196 on 29 September 2016). 